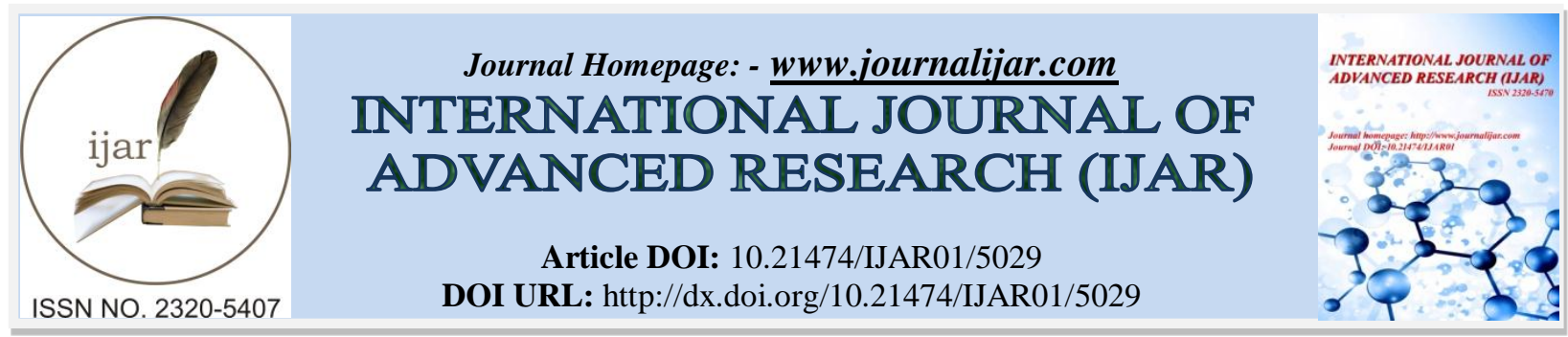

RESEARCH ARTICLE

\title{
SERUM LIPID LEVELS, AND RELATION OF STROKE WITH DIFFERENT COMPONENTS OF SERUM LIPIDS IN PATIENTS WITH STROKE.
}

Ronia Shawket Kawther.

Bch. Pharmacy, MSC Medical microbiology kurdiatani board of medical specialist.

\section{Manuscript Info}

Manuscript History

Received: 01 June 2017

Final Accepted: 03 July 2017

Published: August 2017

\section{Abstract}

Background: A stroke occurs when a blood vessel that carries oxygen and nutrients to the brain either bursts, ruptures or is blocked by a clot. As a result, the brain cannot get the blood and oxygen it needs and pieces of the brain die. Stroke Risk Factors though some stroke risk factors are uncontrollable, such as age and race, other risk factors are controllable For example, hypertension, smoking. This case-control study Focus on the role lipid wich involved serum cholesterol ,serum triglyceride, serum hight density lipoprotein ,serum low density lipoprotein

Aims and objectives: 1 . To know several reasons and risk factors lead to developing trokes.

2.Are lipid profile changes thought to be a risk factor in theoccurrence of stroke.

Patients and methods: This study is a cross sectional study conducted in the Neurology department of Rhizgary teaching hospital in Erbil city in Iraqi Kurdistan from November 2015- September, 2016 comprised 90 patients (50) males and (40) females were diagnosed on the basis of clinical to have strock to see the relation different components of serum lipids and ischemic stroke.

Healthy control (HC) group: fourty healthy individuals comprised of 10 males and 30 females (mean age of total 40 healthy control was $35.5 \pm 5.6$ years) had been chosen from hospital medical staff, who have no history or clinical evidence of stroke or any chronic disease, they were age and sex matched their ages ranged from 27 to 55 years.

Result: Result showed that ischemic stroke was more common after the age of 50 years with mean age of $(56.428 \pm 12.499)$ years. Male suffered more than female from ischemic stroke (M:F=3:1). Hypertension and diabetes mellitus (DM) were found to be highly significant risk factors for ischemic stroke $(\mathrm{P}<0.01)$. High level of both serum triglyceride ,low density lipoprotein (LDL) showed highly significant $(\mathrm{p}<0.01)$. Inaddition, low level of high density lipoprotein $(\mathrm{HDL})$ appeared as a highly significant risk factor $(\mathrm{p}<0.01)$ In contrast to cholesterol level on showed no significant effect on ischemic stroke ( $>>0.05$ ).

Conclusions: We could be concluded that TG,HDL LDL, cholesterol levels can be considered as a risk factor for both ischemic cerebral and 
stroke events. The main risk factor for stroke is high blood pressure. In addition, diabetes mellitus.

Copy Right, IJAR, 2017,. All rights reserved.

\section{Introduction:-}

Stroke is when poor blood flow to the brain results in cell death. There are two main types of stroke ischemic, due to lack of blood flow, and hemorrhagic, due to bleeding. They result in part of the brain not functioning properly[1]. Signs and symptoms of a stroke may include an inability to move or feel on one side of the body, problems understanding or speaking, feeling like the world is spinning, or loss of vision to one side.[2][3]The main predisposing factor for stroke is high blood pressure.[4] In addition cigarette smoking, diabetes mellitus obesity, increase blood cholesterol, and atrial fibrillation.[2][4]Diagnosis is depend on imaging for example a CT scan or magnetic resonance imaging (MRI) scan Beside clinical findings . I n addition blood tests [5].

Dyslipidemia is a potent predictor of cardiovascular morbidity and mortality in diabetic patients. Diabetes mellitus is a common metabolic disorder characterized by absolute or relative deficiencies in insulin secretion and/or insulin action associated with chronic hyperglycemia and disturbances of carbohydrate, lipid and protein metabolism [6] Research findings show that mainly body fat is responsible for increase in prevalence of this disease among the body composition components [7] The term diabetic dyslipidemia comprises a triad of raised triglycerides, reduced high density lipoprotein (HDL) and excess of small, dense low density lipoprotein (LDL) particles. The lipid abnormalities are prevalent in diabetes mellitus because insulin resistance or deficiency affects key enzymes and pathways in lipid metabolism [8] Micro-vascular and macro-vascular complications, including cardiovascular disease (CVD), retinopathy, nephropathy, and neuropathy, occur due to chronic uncontrolled hyperglycemia in diabetics [9, ]. It has been proposed that the composition of lipid particles in diabetic dyslipidemia is more atherogenic than other types of dyslipidemia [10]

\section{Materials and Methods:-}

Patients group This study is a cross sectional study conducted in the Neurology department of Rhizgary teaching hospital in Erbil city in Iraqi Kurdistan from November 2015 September 2016 comprised 90 patients (50) males and (40) females The mean age of total 90 patients was $(56.428 \pm 12.499)$ and their ages ranged from 40-72 years, The patient were diagnosed on the basis of clinical to have strock to see the relation different components of serum lipids and ischemic stroke. Patients were subjected for a questionnaire on the disease manifestation, and their medical histories reviewed for clinical features and previous serological findings after verbal acceptance from each one to participate in research but with out mension any private information. The majority of patients were under regular treatment of either one or more drugs including.antiplatelet,antihyperlipidemic drug, oral hypoglycemic agents.

Healthy group :Fourty healthy individuals comprised of 10 males and 30 females (mean age of total 40 healthy control was $35.5 \pm 5.6$ years), had been chosen from hospital medical staff, who have no history or clinical evidence of stroke or any chronic disease, they were age and sex matched their ages ranged from 27 to 55 years, exclusion criteria wich included young patients.

\section{Recommended ranges:-}

In 2002, the National Cholesterol Education Program (NCEP) Adult Treatment Panel III provided the guidelines for evaluating lipid levels[11]

LDL

Optimal: Less than $100 \mathrm{mg} / \mathrm{dL}(2.59 \mathrm{mmol} / \mathrm{L})$; for those with known disease (ASCVD or diabetes), less than 70 $\mathrm{mg} / \mathrm{dL}(1.81 \mathrm{mmol} / \mathrm{L})$ is optimal

Total Cholesterol

Desirable: Less than $200 \mathrm{mg} / \mathrm{dL}(5.18 \mathrm{mmol} / \mathrm{L})$

HDL

Low level, increased risk: Less than $40 \mathrm{mg} / \mathrm{dL}(1.0 \mathrm{mmol} / \mathrm{L})$ for men and less than $50 \mathrm{mg} / \mathrm{dL}(1.3 \mathrm{mmol} / \mathrm{L})$ for women .Average level, average risk: $40-50 \mathrm{mg} / \mathrm{dL}(1.0-1.3 \mathrm{mmol} / \mathrm{L})$ for men and between $50-59 \mathrm{mg} / \mathrm{dl}(1.3-1.5$ $\mathrm{mmol} / \mathrm{L})$ for women .High level, less than average risk: $60 \mathrm{mg} / \mathrm{dL}(1.55 \mathrm{mmol} / \mathrm{L})$ or higher for both men and women 


\section{Fasting Triglycerides:-}

Desirable: Less than $150 \mathrm{mg} / \mathrm{dL}$ (1.70 mmol/L).Borderline high: $150-199 \mathrm{mg} / \mathrm{dL}(1.7-2.2 \mathrm{mmol} / \mathrm{L})$.High: 200-499 $\mathrm{mg} / \mathrm{dL}(2.3-5.6 \mathrm{mmol} / \mathrm{L})$

Test Principle Enzymatic methods

It is an enzymatic analysis (which is widely used in medical laboratories) the color reaction is preceded by a reaction catalyzed by an enzymeand it is quantitative determination of Cholesterol (CHOD-PAP method).

Triglycerides (GPO-PAP method).

Cholesterol CHOD PAP Method.

Copper (Cu++) Oxidized Human Low Density Lipoprotein (LDL)

High density lipoprotein (HDL) cholesterol measurements are performed after the separation of HDL from the rest of serum lipoproteins. This can be accomplished by ultracentrifugation at $1.063 \mathrm{~kg} / \mathrm{L}$ ( $18 \mathrm{hrs}, 10^{\circ} \mathrm{C}$., at $\left.40,000 \mathrm{rpm}\right)$

\section{Results:-}

The mean age of total 90 patients was $(56.428 \pm 12.499)$ and their ages ranged from $40-72$ years

This study shows that The number of male(M) suffered from stroke is more than female (F)and the proportion was $(\mathrm{M}: \mathrm{F}=3: 1)$

Fig1:- The number of male suffered from stroke is more than female (M:F=3:1)

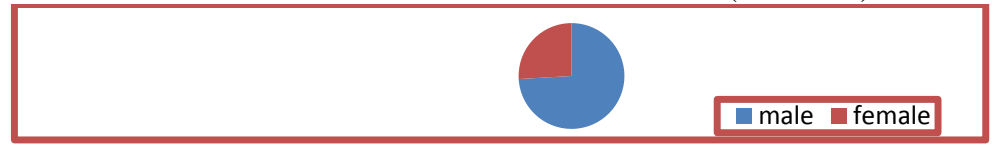

The majorty of the patients suffer from Hypertension and DM.,in addition many patients suffer from both

Tab 2:- Hight relation between the occurrence of stroke with hypertension and DM

\begin{tabular}{|l|l|l|l|}
\hline $\begin{array}{l}\text { Total number of } \\
\text { patients }\end{array}$ & $\begin{array}{l}\text { Number of Patients with History } \\
\text { ofHypertension }\end{array}$ & Number of Patients with History of D.M \\
\hline$=90$ & $80(90 \%)$ & $72(80 \%)$ \\
\hline
\end{tabular}

High level of both serum triglyceride, low density lipoprotein (LDL) showed highly significant $(\mathrm{p}<0.01)$. In addition, low level of high density lipoprotein (HDL) appeared as a highly significant risk factor $(\mathrm{p}<0.01)$. In contrast to cholesterol level on showed no significant effect on ischemic stroke $(p>0.05)$.

Table(3) the relation between the occurrence of stroke and serum lipids components

\begin{tabular}{|l|l|l|c|l|}
\hline & The number of Patients=90 & $\begin{array}{c}\text { The number of } \\
\text { Normal group=40 }\end{array}$ & T. Test & P value \\
\cline { 1 - 3 } Serum component & mean \pm sd & mean \pm sd & & \\
\hline HDL & $53.598 \pm 15.057$ & $56.428 \pm 11.07$ & 0.0008 & $\mathrm{P}<0.01$ \\
\hline LDL & $92.727 \pm 37.656$ & $76 \pm 12.38278375$ & 0.0009 & $\mathrm{P}<0.01$ \\
\hline cholesterol & $142 \pm 47.596$ & $158.571 \pm 8.997$ & 0.639 & $\mathrm{p}>0.05$ \\
\hline Triglyceride(male,female) & & & & \\
\cline { 1 - 2 } Male $=50$ & $160.6176 \pm 57.318$ & $70 \pm 15$ & 0.0002 & \\
\hline Female $=40$ & $157.166 \pm 26.472$ & $60 \pm 10.67187373$ & 0.0001 & \\
\hline
\end{tabular}

$\mathrm{P}<0.01$ Highly significant; $>0.05$ Nonsignificant

\section{Discussion:-}

Stroke makes a principle role in morbidity and mortality and is one of the important causes of death worldwide. There are various reasons and risk factors have action on the developing strokes.

In the conducted study, we compared the data on the lipid profile of the patients with stroke and the normal control group. Findings showed the number of male suffered from stroke is more than female (M:F=3:1)As well, stroke is 
more common among men, but women are more severely ill. Male sex may be a stronger risk factor for stroke than previously stated.[12]. In addition ahigh relation between the occurrence of strokes with hypertension and DM, stroke patients were first diagnosed as hypertensive at presentation with stroke [13].There has been a significant increase in obesity rates worldwide with the corresponding surge in diabetes. Diabetes causes various microvascular and macrovascular changes often culminating in major clinical complications, [14]

A highly significant relation between lipid profile and the occurrence of the ischemic stroke. . Lipid profile changes are might be a risk factor in the developig of stroke. On the other hand, stroke itself is also associated with changes in the lipid levels probably because of the accompanying stress and increase production of catecholamine that occurs during an acute stroke. [15].

cholesterol, however, was not reported to have a considerable role in the development of ischemic stroke. As well as in the other study there was absence of any detectable association between cholesterol and stroke [16] this can be justify by the effect of drug that are used by the patient.

Triglyceride was an important predisposing factors for stroke, while another study showed that no role for TG in the ischemic strokes .LDL was considered as a predictor of hemorrhagic stroke, as well, It is reported that increased LDL levels are associated with higher risk of developing ischemic stroke. [17,18], low level of high density lipoprotein (HDL)as well as. Denti et al reported that low HDL-C levels were associated with higher stroke risk [19].

\section{Conclusion:-}

Concluded that TG,HDL LDL, cholesterol levels chang can be considered as a risk factor for both ischemic cerebral and stroke events.as well the main risk factor for stroke is high blood pressure and diabetes mellitus

\section{References:-}

1. "What Is a Stroke?". www.nhlbi.nih.gov/. March 26, 2014. Retrieved 26 February 2015.

2. Donnan GA, Fisher M, Macleod M, Davis SM (May 2008). "Stroke". Lancet. 371 (9624): $1612-23$. doi:10.1016/S0140-6736(08)60694-7. PMID 18468545.

3. "What Are the Signs and Symptoms of a Stroke?". http://www.nhlbi.nih.gov. March 26, 2014. Retrieved 27 February 2015. External link in |website= (help)

4. "Who Is at Risk for a Stroke?". www.nhlbi.nih.gov. March 26, 2014. Retrieved 27 February 2015

5. "How Is a Stroke Diagnosed?". http://www.nhlbi.nih.gov. March 26, 2014. Retrieved 27 February 2015

6. Abou-Seif MA, Youssef AA. Evaluation of some biochemical changes in diabetic patients. Clin Chim Acta. 2004;346:161-170. doi: 10.1016/j.cccn.2004.03.030. [PubMed]

7. Elinasri HA, Ahmed AM. Patterns of lipid changes among type 2 diabetes patients in Sudan. East Mediterr Health J. 2008;14(2):314-324.

8. Taskinen MR. Diabetic dyslipidemia. Atheroscler Suppl. 2002;3(1):47-51. doi: 10.1016/S1567-5688(01)00006$\mathrm{X}$.

9. Folli F, Corradi D, Fanti P, Davalli A, Paez A, Giaccari A, Perego C, Muscogiuri G. The role of oxidative stress in the pathogenesis of type 2 diabetes mellitus micro- and macrovascular complications: avenues for a mechanistic-based therapeutic approach. Curr Diabetes Rev. 2011;7(5):313-324. doi: 10.2174/157339911797415585.

10. Mahato RV, Gyawali P, Raut PP, Regmi P, Khelanand PS, Dipendra RP, Gyawali P. Association between glycaemic control and serum lipid profile in type 2 diabetic patients: glycated haemoglobin as a dual biomarker. Biomed Res. 2011;22(3):375-380.

11. : Understanding Cholesterol Numbers[ Online] .2010

12. $\triangleleft$ Sacco RL. Stroke risk factors: an overview. In: Norris JW, Hachinski V, eds. Stroke Prevention. New York: Oxford University Press; 2001: 17-42.

13. Owolabi MO1, Risk factors for stroke among patients with hypertension: a case-control study. Agunloye AM. J Neurol Sci. 2013 Feb 15;325(1-2):51-6. doi: 10.1016/j.jns.2012.11.016. Epub 2012 Dec 20.

14. Heidenreich PA, Trogdon JG, Khavjou OA, et al. Forecasting the future of cardiovascular disease in the United States: a policy statement from the American Heart Association. Circulation. 2011;123:933-944.

15. Adibhatla R, Hatcher J. Altered Lipid Metabolism in Brain Injury and Disorders. Subcell Biochem. 2008;49:241-68. 
16. Respective studies collaboration. Cholesterol, diastolic blood pressure, and stroke: 13000 strokes in 450000 people in 45 prospective cohorts. Lancet. 1995;346:1647-53.

17. Amarenco P, Labreuche J. Lipid management in the prevention of stroke: review and updated meta-analysis of statins for stroke prevention. The Lancet Neurology. 2009;8:453-463.

18. Anette Varbo, Børge G. Nordestgaard, Anne Tybjærg-Hansen, Peter Schnohr, Gorm B. Jensen, Marianne Benn. Non-fasting Triglycerides, Cholesterol and Stroke in the General Population. Annals of Neurology. 2011;69:628-634.

19. Denti L, Cecchetti A, Annoni V, et al. The role of lipid profile in determining the risk of ischemic stroke in the elderly: a case/control study. Arch Gerontol Geriatr. 2003;37:51-62. 